\title{
Antibacterial Effect of Silver Nanoparticles Against Four Foodborne Pathogens
}

\author{
Mehdi Zarei ${ }^{1, *} ;$ Amirhesam Jamnejad $^{1}$; Elahe Khajehali $^{2}$ \\ ${ }^{1}$ Department of Food Hygiene, Faculty of Veterinary Medicine, Shahid Chamran University of Ahvaz, Ahvaz, IR Iran \\ ${ }^{2}$ Department of Food Hygiene, Faculty of Veterinary Medicine, Shiraz University of Medical Sciences, Shiraz, IR Iran \\ ${ }^{*}$ Corresponding author: Mehdi Zarei, Department of Food Hygiene, Faculty of Veterinary Medicine, Shahid Chamran University of Ahvaz, Postal Code: 61355-145, Ahvaz, IR Iran. Tel: \\ +98-9173021142, Fax: +98-6113360807, E-mail: zarei@scu.ac.ir
}

Received: October 23, 2012; Revised: January 20, 2013; Accepted: January 27, 2013

\begin{abstract}
Background: There is increased demand for improved disinfection methods due to microorganisms resistant to multiple antimicrobial agents. Numerous types of disinfectants are available with different properties; but the proper disinfectant must be carefully selected for any specific application to obtain the desired antimicrobial effect.

Objectives:Antimicrobial effect of a commercialnanosilver product, NanoCid@ L2000, against some foodborne pathogens was evaluated. Materials and Methods: Minimum inhibitory concentrations (MIC) were determined by monitoring the growth of bacteria at $600 \mathrm{~nm}$, after 24 hours incubation at $35^{\circ} \mathrm{C}$. Minimum bactericidal concentrations (MBC) were determined based on $3 \log$ decrease in the viable population of the pathogens after incubation of nutrient agar plates at $35^{\circ} \mathrm{C}$ for 24 hours. The required exposure time for $3 \log$ reduction in the viable population of the tested pathogens was determined as the minimum exposure time for efficient bactericidal activity. Results: The MIC values of Ag NPs against tested pathogens were in the range of 3.12-6.25 $\mu \mathrm{g} / \mathrm{mL}$. While Listeria monocytogenes showed the MIC value of $6.25 \mu \mathrm{g} / \mathrm{mL}$, Escherichia coli O157:H7, Salmonella typhimurium and Vibrio parahaemolyticus all showed the MIC values of $3.12 \mu \mathrm{g} /$ $\mathrm{mL}$. However, all the pathogens showed the same $\mathrm{MBC}$ value of $6.25 \mu \mathrm{g} / \mathrm{mL}$. To obtain an efficient bactericidal activity against E. coli O157:H7 and S. typhimurium, the exposure time should be at least ca. 6 hours., while this time was ca. 5 hours for V.parahaemolyticus and ca. 7 hours for L. monocytogenes.

Conclusions: Silver nanoparticles showed great antibacterial effectiveness on four important foodborne pathogens. Therefore, Ag NPs could be a good alternative for cleaning and disinfection of equipment and surfaces in food-related environments.
\end{abstract}

Keywords: Silver; Nanoparticles; Pathogen; Disinfection; Microbial Sensitivity Tests

\section{Background}

For many decades, foodborne diseases have been noticed as serious threats to public health all over the world. In foodborne pathogens studies, four major pathogens have emerged significantly important in terms of human health and disease. These include:Escherichia coli $\mathrm{O} 157: \mathrm{H7}$, Listeria monocytogenes, Salmonella typhimurium and Vibrio parahaemolyticus. These organisms have frequently been associated with food products and linked to a number of human illness cases (1). E. coli O157: H7 is an important global cause of diarrhea, hemorrhagic colitis and hemolytic-uremic syndrome. The illness is often linked to the consumption of contaminated and undercooked ground beef as well as unpasteurized fruit juices $(2,3)$.

L. monocytogenes has been implicated in foodborne outbreaks and subsequently isolated from various products such as meat, milk and milk products, vegetables, poultry, and fish (4). Salmonella is an important pathogen that causes major problems of morbidity and mortality around the world. Meat and poultry industries are the main reservoir of Salmonella as a foodborne pathogen. $S$. typhimuriumhas been the most common serotype associated with laboratory-confirmed illness cases $(5,6)$. V.parahaemolyticus is a human pathogen that occurs naturally in the marine environments and has been frequently isolated from a variety of seafood including fish, shrimp, crab, lobster, scallop and oyster (7).

The risk of foodborne diseases can be reduced by adopting some simple precautions such as avoiding cross contamination as well as employing good hygienic practices. One of the major causes of several outbreaks is believed to be lack of or insufficient cleaning and disinfection of equipment and surfaces in food-related environments. Therefore, many of foodborne diseases could be prevented by targeted disinfection in mentioned areas. Numerous types of disinfectants are available with different properties, the proper disinfectant must be selected carefully for the specific application to obtain the required antimicrobial effect (8-10). With the emergence of micro-

Implication for health policy/practice/research/medical education:

Silver nanoparticles showed a great antibacterial effect on four important foodborne pathogens. Therefore, Ag NPs could be a good alternative for cleaning and disinfection of equipment and surfaces in food-related environments.

Copyright @ 2014,Ahvaz Jundishapur University of Medical Sciences; Published by Kowsar Corp. This is an open-access article distributed under the terms of the Creative Commons Attribution License, which permits unrestricted use, distribution, and reproduction in any medium, provided the original work is properly cited. 
organisms, resistant to multiple antimicrobial agents, there is increased demand for improved disinfection methods. Therefore, new technologies have been used for efficient disinfection and microbial control.

During the past few decades, nanotechnology has emerged up as a new promising technology for synthesis of nanomaterials, particles in the nanometer size, which exhibit antimicrobial effects owing to their high surfacearea-to-volume ratio and unique chemical and physical properties $(11,12)$. The bactericidal effects of various metallic nanoparticles including copper, titanium, zinc and silver, have been well documented (13). Silver has been known to have a disinfecting effect as well as applications in traditional medicine and culinary items (14). As early as 1000 B.C. (Before Christ), silver was used to make water potable (15). High antimicrobial efficacy of ionic silver $\left(\mathrm{Ag}^{+}\right)$against a broad spectrum of Gram positive and Gram negative bacteria as well as fungi (16) in combination of low toxicity against human tissue (17) has been led to the wide application of elemental silver or silver compounds in medicine. Hence, Silver nanoparticle (Ag NPs) is a good candidate as an alternative for formulation of a new generation of antibacterial agents used in biological, medical, and pharmaceutical applications (18-20).

\section{Objectives}

The present study was carried out to investigate the antimicrobial effect of a commercial nanosilver product, NanoCid $₫$ L2000, against representative microorganisms of public concern in food-related environments. The antimicrobial effect of silver nanoparticles was assessed by determining the minimum growth inhibitory concentrations (MIC) and minimum bactericidal concentration (MBC). In addition, the minimum exposure time for efficient bactericidal activity of this nanosilver product was determined.

\section{Materials and Methods}

\subsection{Preparation of Nanosilver Solution}

A stock solution of nanosilver with the average size of ca. (about) $10 \mathrm{~nm}$ was prepared from a liquid (L)-form of a nanosilver colloid product (NanoCid@ L2000, Nano Nasb Pars Co., Tehran, Iran). The stock solution was then used to prepare the subsequent dilutions; $100,50,25,12.5,6.25$, 3.12, 1.56 and $0.78 \mu \mathrm{g} / \mathrm{mL}$, using serial two-fold dilutions.

\subsection{Microorganisms}

The stock cultures of E. coli O157:H7 (ATCC 43895), L. monocytogenes (ATCC 7644), S. typhimurium (ATCC 35987) and V. parahaemolyticus (ATCC 35118 ) were stored at $-20^{\circ} \mathrm{C}$ in Tryptic soy broth (TSB) (Merck, Germany) supplemented with $25 \%(\mathrm{v} / \mathrm{v})$ sterile glycerol (Merck, Germany). Test organisms were first activated by two successive trans- fers in TSB at $35^{\circ} \mathrm{C}$ for 24 hours.

\subsection{Preparation of the Inoculums}

$100 \mu \mathrm{L}$ of the overnight cultures of each bacterium were transferred to $10 \mathrm{~mL}$ TSB and incubated at $35^{\circ} \mathrm{C}$ with shaking. Absorbance of the cultures were measured at 600 $\mathrm{nm}$ after 5 hours and the viable cell count at this absorbance was determined by plating onto tryptic soy agar (TSA). According to the correlation between absorbance and viable cell count, approximately $105-106 \mathrm{cfu} / \mathrm{mL}$ of each bacterium was inoculated into the wells of the microplates.

\subsection{Determination of MIC and $M B C$}

MIC, defined as the lowest concentration of an antimicrobial agent that inhibits the growth of a microorganism after overnight incubation, was determined by monitoring the growth of bacteria in a microplate reader (Synergy HT, BioTek Instruments) at $600 \mathrm{~nm}$. Serial twofold dilutions of nanosilver solution were prepared in sterile 96-well plates over the range of $0.78-100 \mu \mathrm{g} / \mathrm{mL}$. The wells were then inoculated with diluted overnight broth culture to give the initial population of $105-106$ $\mathrm{cfu} / \mathrm{mL}$ and incubated at $35^{\circ} \mathrm{C}$ for 24 hours. The bacterial growth was defined as absorbance increase at $600 \mathrm{~nm}$ with shaking for 30 seconds before reading. All the experiments were carried out at least six times.

MBC, the lowest concentration of nanoparticles that kills $\geq 99.9 \%$ ( $3 \log$ ) of the bacteria, was also determined. For this, samples were taken from the wells showing no growth, spread onto nutrient agar plates and incubated at $35^{\circ} \mathrm{C}$ for 24 hours. MBC was determined based on 3 log decrease in the viable population of the pathogens.

\subsection{Determination of Minimum Exposure Time for Efficient Bactericidal Activity}

To determine the minimum exposure time for efficient bactericidal activity of Ag NPs, the viable populations of all tested bacteria were determined during a period of 8 hours incubation in the absence (controls) or presence (treatments) of the relevant MBCs $(6.25 \mu \mathrm{g} / \mathrm{mL})$. The exposure time needed for $\geq 99.9 \%$ (nanosilver $\log$ ) reduction in the viable population of the tested pathogens was defined as the minimum exposure time for efficient bactericidal activity.

\section{Results}

As shown in Table 1, the MIC values of Ag NPs against tested pathogens were in the range of 3.12-6.25 $\mu \mathrm{g} / \mathrm{mL}$. While L. monocytogenes showed the MIC value of $6.25 \mu \mathrm{g} /$ $\mathrm{mL}$, the three Gram negative tested pathogens showed the MIC values of $3.12 \mu \mathrm{g} / \mathrm{mL}$. However, in our study all the pathogens showed the same MBC values of $6.25 \mu \mathrm{g} / \mathrm{mL}$. 
Table 1. MIC and MBC Values of NanoCid $®$ Against Foodborne Pathogens in Nutrient Broth

\begin{tabular}{lll}
\hline Bacteria & MIC & MBC \\
\hline Escherichia coli 0157:H7 & 3.12 & 6.25 \\
Listeria monocytogenes & 6.25 & 6.25 \\
Salmonella typhimurium & 3.12 & 6.25 \\
Vibrio parahaemolyticus & 3.12 & 6.25 \\
\hline
\end{tabular}

In an attempt to determine the minimum exposure time for efficient bactericidal activity of silver nanoparticles against tested pathogens, our results showed that for $\geq 99.9 \%$ ( $3 \log$ ) reduction in the viable population of $L$. monocytogenes , contact time should be at least ca. 7 hours, while this time was ca. 5 hours for V.parahaemolyticus and ca. 6 hours for E. coli O157:H7 and S. typhimurium. As shown in Figure 1, after ca. 6 hours of incubation, viable populations of E. coli $\mathrm{O} 157: \mathrm{H} 7$ and S. typhimurium decreased from 5.64 and $5.85 \log \mathrm{cfu} / \mathrm{mL}$ to 2.32 and $2.78 \mathrm{log}$ cfu/mL, respectively (Figure $1 \mathrm{~A}$ and $\mathrm{B}$ ). However, viable population of $L$. monocytogenes decreased from 5.59 to $2.46 \log \mathrm{cfu} / \mathrm{mL}$ after ca. 7 hours of incubation and viable population of $V$. parahaemolyticus decreased from 5.87 to $2.75 \log \mathrm{CFU} / \mathrm{mL}$ after ca. 5 hours of incubation.

\section{Discussion}

Antibacterial activity of silver nanoparticles has been demonstrated in several investigations, but the reported MIC values range through a wide extent of variation. Hence, it is difficult to compare their results, because there is no standard protocol for evaluation of antimicrobial activity of nanoparticles and different methods have been used by researchers. In the present study, silver nanoparticles showed good antibacterial activity against all the tested pathogens. The results of MIC and MBC tests revealed a higher MIC value for L. monocytogenes comparing to the other tested pathogens. This may be due to the differences in bacterial cell walls, since Gram negative bacteria have thinner cell wall comparing to Gram positive bacteria (21).

In agreement, Kim et al. reported that $S$. aureus was more resistant against nanosilver than Gram negative $E$. coli (12). However, in our study, the MBC values were identical for all the pathogens. It has been previously stated that bactericidal property of nanoparticles is dependent on the concentration and size of nanoparticles and also the initial bacterial concentration (22). Silver nanoparticles with size of $1-10 \mathrm{~nm}$ have been reported to be most effective against bacteria through direct interaction with bacterial cells (11). For example, MIC was reported to be in the range of $3-25 \mu \mathrm{g} / \mathrm{mL}$ for $E$. coli at initial concentration of 105-108 cfu/mL and colloidal silver nanoparticles with the size range of 2 - $25 \mathrm{~nm}$. Furthermore, Pal et al. found that interaction of nanoparticles with E. coli was shapedependent, since truncated triangular particles showed higher activity compared to spherical and rod-spherical particles (23).
Figure 1. Growth and Survival Profile of the Assessed Bacteria
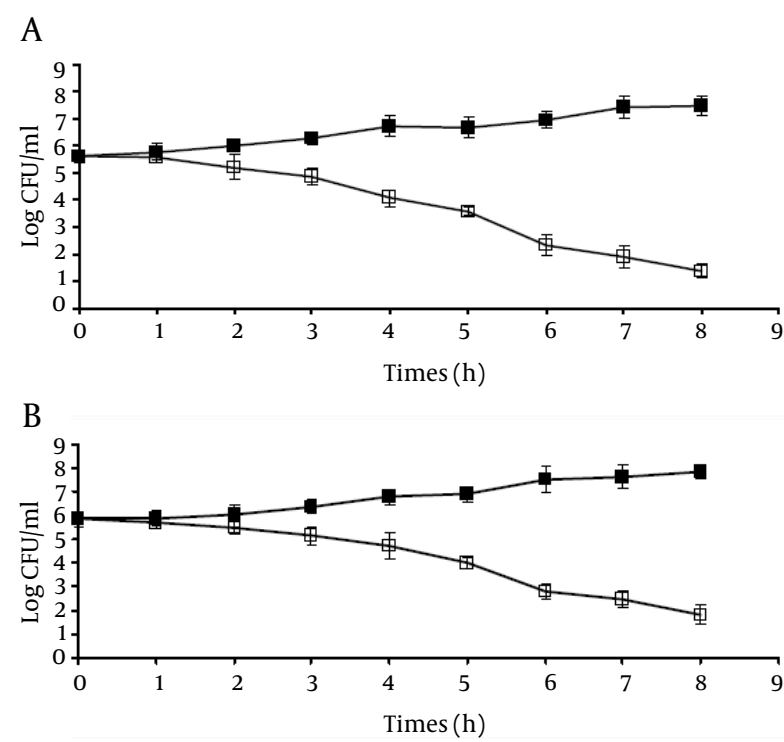

C

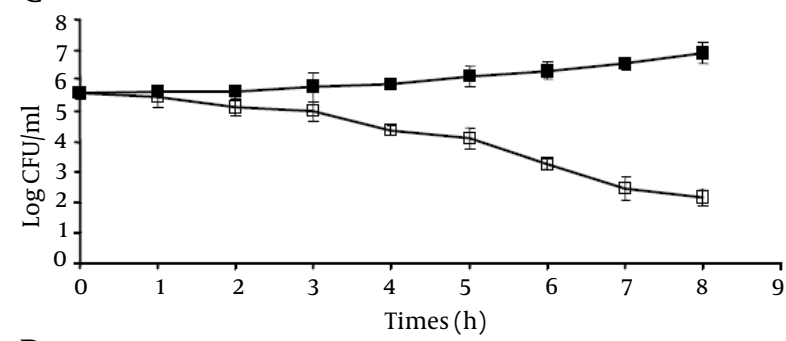

$\mathrm{D}$

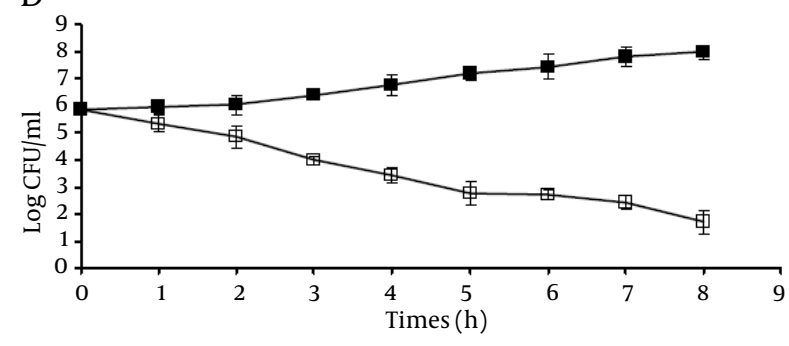

A) E. coli $\mathrm{O} 157: \mathrm{H7}, \mathrm{B})$ S. typhimurium, C) L. monocytogenes, and D) V. parahae molyticus in the absence (controls, $\square$ ) or presence (treatments, $\square$ ) of 6.25 $\mu \mathrm{g} / \mathrm{mL}$ of NanoCid®.

Since, in disinfecting the food-related environment, the exposure time for an efficient bactericidal activity is important, the minimum exposure time for $\geq 99.9 \%$ reduction in the viable population of the pathogens was also determined. The lowest and the highest exposure times were observed for $V$. parahaemolyticus and L. monocytogenes, respectively. As shown in Figure $1 \mathrm{~A}-\mathrm{D}$, in the presence of $6.25 \mu \mathrm{g} / \mathrm{mL}$ silver nanoparticles (relevant MBCs), viable population of all the pathogens decreased as the incubation time increased. However, our results showed that to obtain an efficient bactericidal activity against $E$. coli $\mathrm{O} 157: \mathrm{H7}$ and S. typhimurium, the exposure time should be at least ca. 6 hours, while this time was ca. 5 hours for 
V. parahaemolyticus and ca. 7 hours for L. monocytogenes . Silver nanoparticles showed great antibacterial effects on four important foodborne pathogens. Therefore, with development of multidrug-resistant strains of bacteria, Ag NPs could be good alternatives for cleaning and disinfection of equipment and surfaces in food-related environments.

\section{Acknowledgements}

This study was supported by the research grant provided by Shahid Chamran University of Ahvaz.

\section{Authors' Contribution}

Mehdi Zarei and Elahe Khajehali developed the original idea and the protocol. Amirhesam Jamnejad contributed to the experimental work.

\section{Financial Disclosure}

There is no financial disclosure.

\section{Funding/Support}

This study was supported by the research grant provided by Shahid Chamran University of Ahvaz.

\section{References}

1. Jay JM. Modern Food Microbiology. 6th ed. Singapore: Aspen Publishers; 2000.

2. Armstrong GL, Hollingsworth J, Morris JG, Jr. Emerging foodborne pathogens: Escherichia coli $\mathrm{O} 157: \mathrm{H} 7$ as a model of entry of a new pathogen into the food supply of the developed world. Epidemiol Rev. 1996;18(1):29-51.

3. Griffin PM, Tauxe RV. The epidemiology of infections caused by Escherichia coli $\mathrm{O} 157: \mathrm{H7}$, other enterohemorrhagic E. coli, and the associated hemolytic uremic syndrome. Epidemiol Rev. 1991;13:60-98.

4. Parihar VS, Barbuddhe SB, Danielsson-Tham ML, Tham W. Isolation and characterization of Listeria species from tropical seafoods. Food Cont. 2008;19(6):566-569.

5. Mani-Lopez E, Garcia HS, Lopez-Malo A. Organic acids as antimicrobials to control Salmonella in meat and poultry products. Food Res Int. 2012;45(2):713-721.

6. Moretro T, Heir E, Nesse LL, Vestby LK, Langsrud S. Control of Sal- monella in food related environments by chemical disinfection. Food Res Int. 2012;45(2):532-544.

7. Austin B. Vibrios as causal agents of zoonoses. Vet Microbiol. 2010;140(3-4):310-7.

8. Grinstead D. Cleaning and sanitation in food processing environments for the prevention of biofilm formation and biofilm removal. In: Fratamico PM, Annous BA, Gunther NW editors. Biofilms in the Food and Beverage Industries.. Oxford: Woodhead Publishing; 2009.

9. Cogan TA, Bloomfield SF, Humphrey TJ. The effectiveness of hygiene procedures for prevention of cross-contamination from chicken carcases in the domestic kitchen. Lett Appl Microbiol. 1999;29(5):354-8

10. Cogan TA, Slader J, Bloomfield SF, Humphrey TJ. Achieving hygiene in the domestic kitchen: the effectiveness of commonly used cleaning procedures. J Appl Microbiol. 2002;92(5):885-92.

11. Morones JR, Elechiguerra JL, Camacho A, Holt K, Kouri JB, Ramirez JT, et al. The bactericidal effect of silver nanoparticles. Nanotechnology. 2005;16(10):2346-53.

12. Kim JS, Kuk E, Yu KN, Kim JH, Park SJ, Lee HJ, et al. Antimicrobial effects of silver nanoparticles. Nanomedicine. 2007;3(1):95-101.

13. Schabes-Retchkiman PS, Canizal G, Herrera-Becerra R, Zorrilla C Liu HB, Ascencio JA. Biosynthesis and characterization of Ti/Ni bimetallic nanoparticles. Opt Mater. 2006;29(1):95-99.

14. Shrivastava S, Bera T, Roy A, Singh G, Ramachandrarao P, Dash D Characterization of enhanced antibacterial effects of novel silver nanoparticles. Nanotechnol. 2007;18(22):225103.

15. Castellano JJ, Shafii SM, Ko F, Donate G, Wright TE, Mannari RJ, et al. Comparative evaluation of silver-containing antimicrobial dressings and drugs. Int Wound J. 2007;4(2):114-22.

16. Percival SL, Bowler PG, Russell D. Bacterial resistance to silver in wound care. J Hosp Infect. 2005;60(1):1-7.

17. Damm C, Münstedt $H$, Rösch A. Long-term antimicrobial polyamide 6/silver-nanocomposites. J Mater Sci. 2007;42(15):6067-6073.

18. Brigger I, Dubernet C, Couvreur P. Nanoparticles in cancer therapy and diagnosis. Adv Drug Deliv Rev. 2002;54(5):631-51.

19. Li Y, Leung P, Yao L, Song QW, Newton E. Antimicrobial effect of surgical masks coated with nanoparticles. J Hosp Infect. 2006;62(1):58-63.

20. Tian J, Wong KK, Ho CM, Lok CN, Yu WY, Che CM, et al. Topical delivery of silver nanoparticles promotes wound healing. ChemMedChem. 2007;2(1):129-36.

21. Rai M, Yadav A, Gade A. Silver nanoparticles as a new generation of antimicrobials. Biotechnol Adv. 2009;27(1):76-83.

22. Ruparelia JP, Chatterjee AK, Duttagupta SP, Mukherji S. Strain specificity in antimicrobial activity of silver and copper nanoparticles. Acta Biomater. 2008;4(3):707-16.

23. Pal S, Tak YK, Song JM. Does the antibacterial activity of silver nanoparticles depend on the shape of the nanoparticle? A study of the Gram-negative bacterium Escherichia coli. Appl Environ Microbiol. 2007;73(6):1712-20. 